\title{
Adaptation of tall-grass prairie cultivars to West Louisiana
}

\author{
W.D. PITMAN
}

Author is associate professor, Louisiana State University Agricultural Center, Rosepine Research Station, Rosepine, La. 70659.

\begin{abstract}
Big bluestem (Andropogon gerardii Vitman) indiangrass [Sorghastrum nutans (L.) Nash] and switchgrass (Panicum virga tum L.) are widely recognized as valuable forage and conservation species in the Great Plains and the upper South. These species occurred in natural fire-maintained longleaf pine (Pinus palustris Mill.) woodland ecosystems from southeast Texas eastward. Recent interest and even recommendations of cultivars of these species have been developed in the Louisiana longleaf pine area. Genotype origin of these species is known to affect adaptation. Adaptation of the cultivars Kaw big bluestem, Lometa indiangrass, Osage indiangrass, Blackwell switchgrass, and Alamo switchgrass to the Louisiana Coastal Plain was assessed under a natural stand of longleaf pines and in full sun at Rosepine, La. Plots were seeded in 1995, and stands were monitored through the spring of 1998. Only Alamo switchgrass and Lometa indiangrass under the pines produced sufficient stands for harvest. Production potential was greatest for Alamo switchgrass with the highest annual yield of $5,580 \mathrm{~kg} \mathrm{ha}^{-1}$ from 2 harvests in 1996. Herbage production of $1,500 \mathrm{~kg} \mathrm{ha}^{-1}$ did not differ between Alamo switchgrass and Lometa indiangrass in the second year of harvest when harvested in June and September for 2 consecutive years. The longleaf pine overstory apparently provided a competitive advantage during establishment, since weeds dominated plots in full sun. The 2 cultivars from southern latitudes, Alamo switchgrass and Lometa indiangrass, were superior in establishment, productivity, and stand survival. Aggressive competition from dense-growing subtropical grasses was detrimental during establishment and following defoliation.
\end{abstract}

Key Words: big bluestem, indiangrass, switchgrass, Coastal Plain

Livestock production is a traditional use of longleaf pine forests in the Southeast due to relatively abundant forage production (Grelen 1974). Lightning-caused fires allowed a longleaf pinebluestem subclimax community to persist on the lower Coastal Plain from East Texas to West Florida (Grelen and Duvall 1966). Langdon et al. (1952) suggested that, "The bluestem forage type of Louisiana and east Texas is essentially a woodland continuation of the tall grass prairie, ..." The productive, palatable grasses big bluestem, indiangrass, and switchgrass occurred throughout the region. However, they were not abundant, and their frequency of occurrence decreased even under moderate grazing pressure (Grelen and Duvall 1966; Byrd 1980). Currently, extensive areas of commercial timber land in this region are not grazed. Wildfire control and limited use of controlled burning

Louisiana Agricultural Experiment Station manuscript number 98-92-0252.

Manuscript accepted 11 Mar. 1999.
Resumen

En las regiones Great Plains y Upper South las especies "Big bluestem" (Andropogon gerardii Vitman), "Indiangrass" [Sorghastrum nutans (L.) Nash] y "Switchgrass" (Panicum virga tum L.) son ampliamente reconocidos como valiosas especies forrajeras y de conservación. Estas especies, ocurren en forma natural en los ecosistemas forestales de "Longleaf pine" (Pinus palustris Mill.) del Sudeste de Texas. Recomendaciones de cultivares de estas especies han sido desarrolladas en el área de "Longleaf pine" de Louisiana. Se sabe que el origen de los genotipos de estas especies afecta la adaptación. Se evaluó la adaptación de los cultivares "Kaw" ("Big bluestem"), "Lometa" ("Indiangrass"), "Osage" ("Indiangrass"), 'Blackwell' ("Switchgrass") y "Alamo" ("Switchgrass") a las planicies costeras de Louisiana en una población natural de "Longleaf pine" y en condiciones de iluminación solar total en Rosepine, Louisiana. Las parcelas se sembraron en 1995 y las poblaciones de zacates se monitorearon de 1995 hasta la primavera de 1998. Bajo los pinos, solo los cultivares "Alamo" ("Switchgrass") y "Lometa" ("Indiangrass") produjeron suficiente forraje para cosecharlo. La producción potencial fue mayor para 'Alamo' y su mayor rendimiento anual fue en 1996 con $5,500 \mathrm{~kg} \mathrm{ha}^{-1}$ obtenidos en dos cortes. En el segundo año consecutivo de cosecha, la producción de "Alamo" ("Switchgrass") y "Lometa" ("Indiangrass") fue de $1,500 \mathrm{~kg} \mathrm{ha}^{-1}$ para ambos cultivares cuando se cosecharen en Junio y Septiembre durante 2 años consecutivos. Durante el establecimiento, la biomasa aérea de "Longleaf pine" aparentemente proveyó una ventaja competitiva, ya que la maleza domino en las parcelas con iluminación solar total. Los dos cultivares de las latitudes del sur. 'Alamo' ("Switchgrass") y "Lometa" ("Indiangrass") fueron superiores en establecimiento, productividad y sobrevivencia de la población. La competencia agresiva de los zacates subtropicales de crecimiento denso fue detrimental durante el establecimiento y después en de la defoliación.

contribute to increased occurrence of loblolly pine (Pinus taeda L.), slash pine ( $P$. elliottii Engelm), and mixed hardwoods. These trees reduce herbaceous understory vegetation. Following timber harvest, slash and loblolly pines are often planted rather than the more open-growing longleaf pine (Grelen and Duvall 1966). Fencing laws associated with highway safety led to additional decreases in grazing, since the low stocking rates and open range grazing practices often made the necessary fencing uneconomical. Thus, the longleaf pine-bluestem forested range of the lower South has been greatly reduced in area and economic importance as a grazing resource.

The forestry and livestock industries in the region have become highly specialized, distinct enterprises rather than the integrated 
enterprises of the past. Livestock production is primarily based on introduced pastures of bermudagrass [Cynodon dactylon (L.) Pers.] and bahiagrass (Paspalum nota tum Flugge var. saurae Parodi ). Several limitations of these well adapted, highly productive, grazing tolerant, introduced grasses have contributed to continuing interest in the native grass species. Beaty and Powell (1976) noted that switchgrass growth began 60 days earlier than bahiagrass or bermudagrass on the Coastal Plain in Georgia. Their evaluation indicated that with appropriate defoliation management, switchgrass could provide spring grazing and some dormant-season forage. A 1991 compilation of information regarding adaptation of selected native grasses identified several cultivars of big bluestem, indiangrass, and switchgrass as adapted to the southeastern states (Everett, 1991). This publication indicated that forage, either grazing or hay production, was an appropriate use of these grasses in particular areas within the region. Unfortunately, these generalizations were made with limited field data and no actual evaluations of most cultivars on the west Louisiana Coastal Plain. Recent interest in these species for conservation uses such as buffer strips, plantings for wildlife cover, and natural area restoration provide additional possibilities. Everett's (1991) compilation included 16 switchgrass entries, with 5 of these reported as adapted to at least part of the Coastal Plain in Louisiana. Only 1 of these, Alamo switchgrass, originated from a latitude similar to that of the Louisiana Coastal Plain. Of the 10 indiangrass entries, 4 were noted as adapted within the Louisiana Coastal Plain area, with only Lometa indiangrass originating at a similar latitude. Of 7 big bluestem entries, only Kaw, which originated at a much higher latitude, was shown as adapted within Louisiana. Early evaluations of ecotypes of these species demonstrated latitude-related differences in flowering date and dormancy initiation (McMillan 1959; Newell 1968). Recently, geographical origin of genotypes of tallgrass species has been suggested to affect adaptation through both photoperiod effect and through susceptibility to foliar diseases associated with precipitation zones (Moser and Vogel 1995). Thus, cultivars should be developed from ecotypes originating near the area of intended use. Information on suitability of available cultivars of the tall-grass species for the Louisiana Coastal Plain is needed. The objective of this research was to assess the adaptation of selected cultivars of switch- grass, big bluestem, and indiangrass on a site representative of the west Louisiana Coastal Plain.

\section{Materials and Methods}

\section{Experiment I}

Field plots of 5 tall-grass cultivars were established under a natural stand of longleaf pines at Rosepine, La. (30 $57^{\circ} \mathrm{N}$, $93^{\circ} 20^{\prime} \mathrm{W}, 67 \mathrm{~m}$ elevation) in 1995 . A randomized complete block design with 6 replications was used. Cultivars evaluated were Alamo switchgrass, Blackwell switchgrass, Kaw big bluestem, Lometa indiangrass, and Osage indiangrass. Seeding rates were $5 \mathrm{~kg}$ PLS ha ${ }^{-1}$ for switchgrass, $15 \mathrm{~kg}$ PLS ha ${ }^{-1}$ for big bluestem, and $11 \mathrm{~kg} \mathrm{PLS} \mathrm{ha}{ }^{-1}$ for indiangrass. Plots were 6 by $50 \mathrm{~m}$. The soil was a Bowie fine sandy loam (loamy, siliceous, thermic Plinthic Paleudult) with initial soil $\mathrm{P}$ of $33 \mathrm{mg} \mathrm{kg}^{-1}, \mathrm{~K}$ of $55 \mathrm{mg} \mathrm{kg}^{-1}, \mathrm{Ca}$ of $320 \mathrm{mg} \mathrm{kg}^{-1}$, Mg of $98 \mathrm{mg} \mathrm{kg}^{-1}$, and $\mathrm{pH}$ of 5.8. An existing stand of bahiagrass was sprayed with 11.5 liters ha ${ }^{-1}$ of glyphosate [N-(phosphonomethyl) glycine] herbicide in April 1995. A rough seedbed was prepared by disking in late May and again in early June. Seed were broadcast by hand on 7 June 1995 and packed with a roller immediately following sowing.

This experiment was located within a 4ha stand of 45- to 50-year-old longleaf pines. The tree stand had been thinned to an average $11.5 \mathrm{~m}^{2}$ basal area $\mathrm{ha}^{-1}$ in the summer of 1986. A solid stand of bahiagrass was present in April 1995, and pasture management practices had prevented development of a woody plant understory.

Visual stand ratings were made in Oct. 1995, June 1996, Oct. 1996, Oct. 1997, and June 1998. Stand ratings were based on a scale of 0 to 9 with 0 indicating no plants present and 9 indicating a complete stand of the planted cultivar. Effects of defoliation on productivity and persistence were assessed by sampling at different frequencies and seasons. Two, $1.5-$ by $6-\mathrm{m}$ areas per plot were sampled for each defoliation treatment at a $20-\mathrm{cm}$ stubble height. The 4 defoliation treatments were (1) harvest in June 1996, Sept. 1996, June 1997, and Sept. 1997; (2) harvest in Sept. 1996 and Sept. 1997; (3) harvest in June 1997 and Sept. 1997; and (4) harvest only in Sept. 1997. Harvested samples were weighed and subsampled for dry matter determination, and dry matter yields were calculated. As an index of shade by the longleaf pine overstory, measurements of photosynthetically active radiation were made during 6 days in late July and early August 1997. Each day, 1 replication was evaluated with 6 readings taken from each plot between 1100 and 1300 hours. Readings were taken only on days with clear sky conditions. The point quantum sensor for the LI-COR Model LI-189 light meter (LI-COR Inc., Lincoln, Nebr.) was held at the top of the grass canopy for each reading.

Statistical analyses included analysis of variance and treatment means comparisons by least significant difference procedures at each assessment date for both visual stand ratings and herbage mass. Herbage mass at each clipping date and total annual dry matter production for each year were compared among clipping treatments.

\section{Experiment II}

The same 5 tall-grass cultivars evaluated in Experiment I were planted on an adjacent site in full sunlight. This site had the same soil type with only slightly different analysis $\left(\mathrm{P}, 25 \mathrm{mg} \mathrm{kg}^{-1} ; \mathrm{K}, 45 \mathrm{mg} \mathrm{kg}^{-1}\right.$; Ca, $431 \mathrm{mg} \mathrm{kg}^{-1} ; \mathrm{Mg}, 93 \mathrm{mg} \mathrm{kg}^{-1}$; and $\mathrm{pH}$, 5.9.) from those of Experiment I. The same seeding rates were used as in Experiment I. Two seedbed types were evaluated with a split-plot arrangement of treatments in a randomized complete block design with 4 replications. Main plots were seedbed types with grass cultivars as subplots. Main plots were 9 by 18 $\mathrm{m}$. Subplots were 3.6 by $9 \mathrm{~m}$. Main plot treatments consisted of a prepared seedbed and the living stubble of a grazed-out ryegrass (Lolium multiflorum Lam.) stand. Planting date was 10 May 1995. Data collected consisted of visual stand ratings in October of each year after planting and in June 1998. Stand ratings were as described for Experiment I. Statistical analysis consisted of analysis of variance at each rating date with assessment of differences among grass cultivars by least significant difference procedures.

\section{Results}

In Experiment I, Alamo switchgrass established earlier and maintained the highest rated stands throughout the 3-year evaluation period (Table 1). At the 2 June evaluation dates (in 1996 and 1998), stand ratings of Lometa indiangrass were not significantly different from those of Alamo switchgrass. The similar stand ratings for these 2 grasses in June were in spite of earlier growth each spring observed for Alamo switchgrass. The con- 
Table 1. Stand ratings ${ }^{1}$ of tall-grass cultivars planted under longleaf pines at Rosepine, La. on 7 June 1995.

\begin{tabular}{lccccc}
\hline \hline & \multicolumn{5}{c}{ Stand rating date } \\
\cline { 2 - 6 } Grass cultivar & Oct. 1995 & June 1996 & Oct. 1996 & Oct. 1997 & June 1998 \\
\hline Alamo switchgrass & $6.2 \mathrm{a}^{2}$ & $7.0 \mathrm{a}$ & $7.8 \mathrm{a}$ & $6.3 \mathrm{a}$ & $6.5 \mathrm{a}$ \\
Blackwell switchgrass & $2.7 \mathrm{bc}$ & $2.5 \mathrm{~b}$ & $2.2 \mathrm{c}$ & $1.2 \mathrm{c}$ & $1.5 \mathrm{~b}$ \\
Kaw big bluestem & $2.0 \mathrm{c}$ & $1.2 \mathrm{~b}$ & $1.2 \mathrm{c}$ & $1.0 \mathrm{c}$ & $1.0 \mathrm{~b}$ \\
Lometa indiangrass & $3.7 \mathrm{~b}$ & $5.3 \mathrm{a}$ & $5.0 \mathrm{~b}$ & $4.0 \mathrm{~b}$ & $5.2 \mathrm{a}$ \\
Osage indiangrass & $2.5 \mathrm{bc}$ & $1.7 \mathrm{~b}$ & $1.2 \mathrm{c}$ & $1.0 \mathrm{c}$ & $1.2 \mathrm{~b}$ \\
\hline
\end{tabular}

${ }^{1}$ Stand ratings are visual ratings based on a scale of 0 for no plants present to 9 for a complete stand.

${ }^{2}$ Means within a column followed by a common letter do not differ $(\mathrm{P}>0.05)$ according to LSD means separation.

sistent superiority of Alamo switchgrass in October ratings suggests relative differences between spring and fall stand density of these 2 grasses. Stands of Lometa indiangrass were superior only to those of Kaw big bluestem in October of the establishment year. At all subsequent rating dates, Lometa indiangrass stands were superior to those of Blackwell switchgrass, Kaw big bluestem, and Osage indiangrass. Stand ratings of these latter 3 cultivars did not differ from one another throughout the experiment. Individual plants of all cultivars produced vigorous growth and matured seed each fall. Despite this seed production, substantial improvement in stand density did not occur following initial establishment. Lack of such stand development is probably associated with the re-establishment of dense bahiagrass stands where sparse tall-grass stands developed in the first year. By fall of 1996, all plots had complete grass cover. Bahiagrass predominated except in the Alamo switchgrass and Lometa indiangrass plots. Substantial portions of plots of these 2 cultivars produced complete canopies which excluded bahiagrass. Only Alamo switchgrass and Lometa indiangrass produced sufficient stands for sampling of standing herbage in plots to reflect productivity of the planted grasses.

Physiological stage at harvest in June for these indeterminate grasses differed considerably within grass stands; however, Alamo switchgrass was predominately from boot to early seedhead exsertion stages, and Lometa indiangrass was primarily at advanced stem elongation stages. In September, previously harvested plants of both species and Lometa indiangrass plants not previously harvested ranged from boot to anthesis stages. Plants of Alamo switchgrass which had not previously been harvested ranged from the seedhead exsertion stage to past anthesis with some seed shattering. Superior production potential was indicated for Alamo switchgrass (Fig. 1). Although numerically greater, yields of Alamo switchgrass were not significantly $(\mathrm{P}>0.05)$ improved by harvesting in both June and September rather than only one annual harvest in September. Yields in a second consecutive year of harvest, whether from 1 or 2 clippings per year, were lower $(\mathrm{P}<0.05)$ than yields from areas not previously clipped. Clipping opened the sampled area, and bahiagrass invaded. Where harvested for 2 consecutive years, Alamo switchgrass only maintained a few sparse plants within a dense bahiagrass stand. In contrast, Lometa indiangrass produced more $(\mathrm{P}<0.05)$ herbage when clipped in both June and September than when clipped only in September. Yields were similar for the two cultivars only in 1997 from areas harvested in both June and September in both years. A single September clipping each year for 2 consecutive years resulted in lower $(\mathrm{P}<0.05)$ herbage yields of

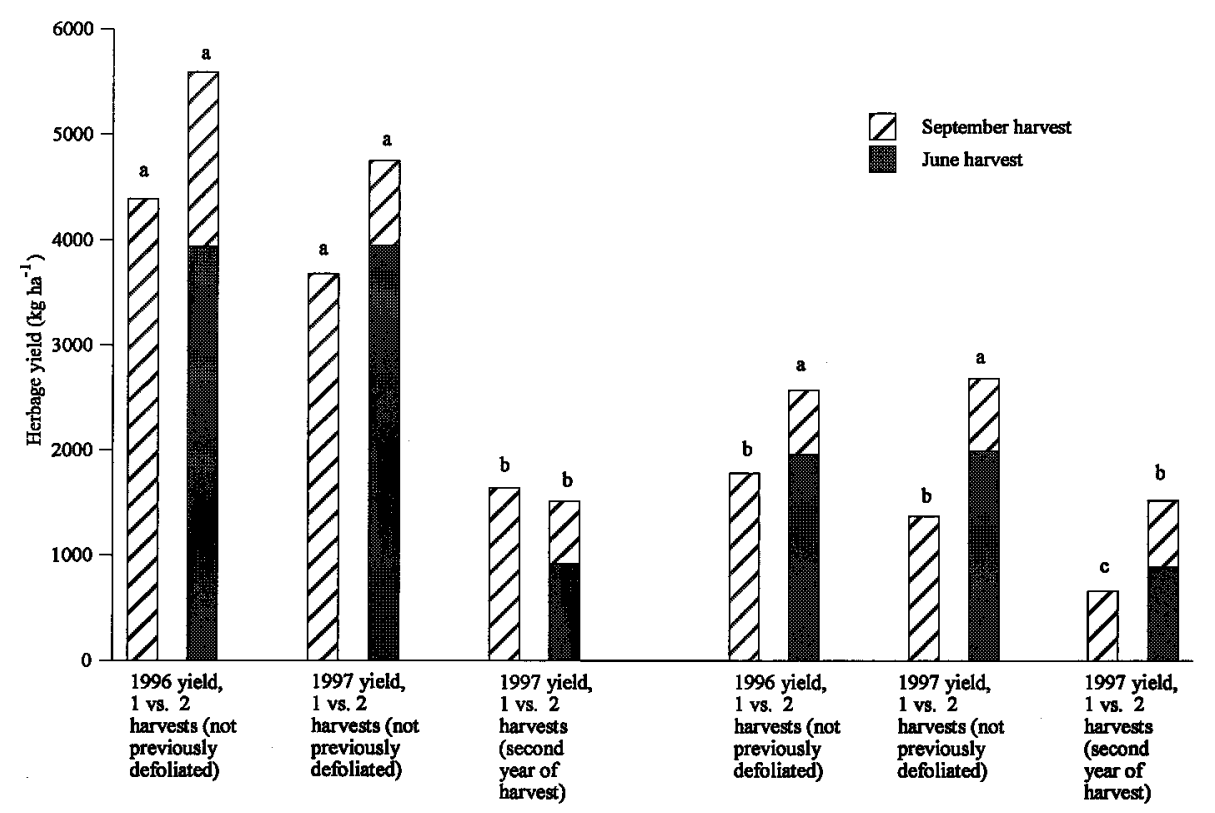

Alamo Switchgrass

Lometa Indiangrass

Fig. 1. Herbage yields of Alamo switchgrass and Lometa indiangrass under a natural longleaf pine stand at Rosepine, La. as affected by clipping treatment. Yields within a species do not differ $(P>0.05)$ for bars marked with a common letter. Yields differed $(P<0.05)$ between species, except in the second year of harvest with 2 clippings. 
Table 2. Stand ratings ${ }^{1}$ of tall-grass cultivars in open-field plantings sown on 10 May 1995 at Rosepine, La.

\begin{tabular}{|c|c|c|c|c|c|c|c|c|c|c|}
\hline \multirow{2}{*}{ Grass cultivar } & \multirow{2}{*}{\multicolumn{3}{|c|}{ Oct. 1996}} & & and rating & & & \multirow{2}{*}{\multicolumn{3}{|c|}{ June 1998}} \\
\hline & & & & & \multicolumn{3}{|c|}{ Oct. 1997} & & & \\
\hline Blackwell switchgrass & $0.5 \mathrm{a}$ & & $1.0 \mathrm{a}$ & & $0.5 \mathrm{a}$ & & $1.8 \mathrm{ab}$ & $0.5 \mathrm{a}$ & $*$ & $2.5 \mathrm{ab}$ \\
\hline Kaw big bluestem & $0.0 \mathrm{a}$ & & $0.5 \mathrm{a}$ & & $0.5 \mathrm{a}$ & & $0.3 \mathrm{~b}$ & $0.8 \mathrm{a}$ & & $0.8 \mathrm{~b}$ \\
\hline Lometa indiangrass & $0.0 \mathrm{a}$ & $*$ & $1.0 \mathrm{a}$ & * & $0.5 \mathrm{a}$ & $*$ & $2.0 \mathrm{ab}$ & $0.5 \mathrm{a}$ & $*$ & $3.0 \mathrm{ab}$ \\
\hline Osage indiangrass & $0.3 \mathrm{a}$ & & $0.8 \mathrm{a}$ & & $0.5 \mathrm{a}$ & & $0.8 \mathrm{~b}$ & $0.5 \mathrm{a}$ & & $0.5 \mathrm{~b}$ \\
\hline
\end{tabular}

${ }^{1}$ Stand ratings are visual ratings based on a scale of 0 for no plants present to 9 for a complete stand.

${ }^{2}$ Means within a column followed by a common letter do not differ ( $\left.\mathrm{P}>0.05\right)$ according to LSD means separation.

${ }^{3}$ Means differ between seedbed treatments for a grass cultivar on a specific rating date when marked by an*.

grass each year. Spring growth of the unfertilized ryegrass was sparse and not productive, but was apparently sufficient to compete with early establishment of warm-season grass seedlings. In the absence of soil disturbance, the summerannual crabgrass competition decreased after the 1995 summer growing season. Due to limited existing seed supplies of bahiagrass and bermudagrass, these species invaded slowly with sparse stands by June 1998 . With this limited competition, stand increases were particularly noticeable for Alamo switchgrass. In October 1997 and June 1998, Alamo switchgrass stands on the original prepared-seedbed treatment were superior to those of Kaw big bluestem and Osage indiangrass. Other treatments did not differ. Sufficient stands of Alamo switchgrass developed by fall of 1997 for samples from 3 plots to be taken to estimate yield potential in full sunlight in this environment. These three samples from 1.2 by $3.0 \mathrm{~m}$ areas of mature plants produced average 1997 growing season biomass of $6,100 \mathrm{~kg} \mathrm{ha}^{-1}$ (with maximum of highest yielding plot of $8,600 \mathrm{~kg} \mathrm{ha}^{-1}$ ).

\section{Discussion}

Planting dates were within the period recommended locally for warm-season forage species and appear appropriate for the tall-grass species. Initial establishment differences between the 2 experiments corresponded with differences in herbaceous plant competition. Shade of longleaf pines reduced competition and enhanced stand establishment. In full sun, dense crabgrass competition was delayed, but not prevented, by the living ryegrass stubble. Even the sparse ryegrass apparently had an early detrimental effect on tallgrass stand establishment. Light measurements taken near noon under the longleaf pine canopy ranged from $10 \%$ to $100 \%$ of full sunlight with an average of $65 \%$ throughout the plot area. This level of light reduction apparently provided a competitive advantage to the tall-grass seedlings. Such a competitive advantage may be necessary for successful establishment of these species under the highly competitive conditions of such a humid environment. Where environmentally acceptable and economically feasible, the benefits of pesticides should be assessed. Herbicide enhancement of tall-grass establishment is apparently influenced by grass species and soil type (Martin et al., 1982). Benefits of insecticide have also been reported (McKenna and Wolf, 1990).

Even following the establishment period, plant competition from aggressive sodforming grasses was a key limitation to survival of the tall-grass species. When not clipped, the adapted tall-grass cultivars were able to maintain stands even though dense bahiagrass stands surrounded the plot. When the tall grasses were defoliated, especially repeatedly, the sod-forming bahiagrass had a distinct competitive advantage and dominated the area within 1 or 2 growing seasons. Even in the tallgrass prairie region, defoliation can reduce dominance by the tall-grass species and increase species diversity (Collins et al. 1998). Cuomo et al. (1996) reported that in Nebraska, switchgrass was the most tolerant of defoliation among these 3 species, however, yields of all 3 species decreased with increased harvest frequency. Haferkamp and Copeland (1984) reported decreases in plant vigor of switchgrass subjected to differing defoliation treatments which were similar to our responses. Their results suggest that removal of apical meristems is a critical factor, especially when repeated a second time in the same growing season. In a review of research on switchgrass for biomass, Sanderson et al. (1996) indicated that yields were similar, or only slightly greater, from 2 harvests per season compared to a single harvest. While our results with Alamo switchgrass are in agreement with this response, Lometa indiangrass consistently produced higher yields from 2 harvests than from a single harvest per season. Haferkamp and Copeland (1984) reported herbage yield increases, but not increased vigor of fall defoliated switchgrass, due to fertilization. In high rainfall environments, fertilization could be detrimental due to increased competition.

Comparisons among cultivars indicate a distinct superiority of Alamo switchgrass, although this advantage over Lometa indiangrass was lost when stands were clipped repeatedly. Responses indicate that observations regarding adaptation of these tall-grass species in the Great Plains region (Voigt and MacLauchlan 1985) also apply to the Coastal Plain region. Cultivars which originated near the same latitude (Alamo switchgrass and Lometa indiangrass) were better adapted than those from more northern latitudes. Not only was this reflected in earlier growth each spring and later growth in the fall for the more southern ecotypes, but establishment success was also improved. Alamo switchgrass was superior despite tolerance of acid soils by seedlings of Blackwell switchgrass (Hopkins and Taliaferro 1997).

Potential exists for establishment and use of Alamo switchgrass and Lometa indiangrass for conservation uses such as buffer zones, for wildlife plantings, and for restoration plantings. Suitability of these grasses for pasture plantings is limited by the distinct competitive advantage of the widespread, aggressive, introduced grasses bahiagrass, bermudagrass, and crabgrass. Shading from open longleaf pine stands, along with low fertility and periodic moisture limitations characteristic of west Louisiana Coastal Plain soils, can reduce the competitiveness of the introduced sod-forming grasses. Defoliation increases the advantage of the sod-forming grasses over the upright growing tall-grass species. Thus, while Alamo switchgrass and Lometa indiangrass are adapted to at 
least some sites on the west Louisiana Coastal Plain, their usefulness appears to be restricted to situations of infrequent defoliation and resource (light, fertility, or moisture) limitations.

\section{References}

Beaty, E.R. and J.D. Powell. 1976. Response of switchgrass (Panicum virgatum L.) to clipping frequency. J. Range Manage. 29:132-135.

Byrd, N.A. 1980. Forestland grazing, a guide for service foresters in the South. Forestry Report SA-FR10. USDA, Forest Service, Southeastern Area, Atlanta, Ga.

Collins, S.L., A.K. Knapp, J.M. Briggs, J.M. Blair, and E.M. Steinauer. 1998. Modulation of diversity by grazing and mowing in native tallgrass prairie. Sci. 280:745-747.

Cuomo, G.J., B.E. Anderson, L.J. Young, and W.W. Wilhelm. 1996. Harvest frequency and burning effects on monocultures of 3 warm-season grasses. J. Range Manage. 49:157-162.

Everett, H. W. 1991. Native perennial warm season grasses for forage in Southeastern United States (except South Florida). USDA, SCS, Ecol. Sci. and Planning Staff, Fort Worth, Tex.
Grelen, H.E. 1974 . Longleaf-slash pinebluestem range, p. 9-12. In: C.E. Lewis, H. E. Grelen, L.D. White, and C.W. Carter (eds.) Range Resources of the South. Bull. N. S. 9, Georgia Agr. Exp. Sta., Athens, Ga. and Southern Section, Soc. for Range Manage.

Grelen, H.E. and V.L. Duvall. 1966. Common plants of longleaf pine-bluestem range. U.S. Forest Service Research Paper SO-23. Southern Forest Exp. Sta., New Orleans, La.

Haferkamp, M.R. and T.D. Copeland. 1984. Shoot growth and development of Alamo switchgrass as influenced by mowing and fertilization. J. Range Manage. 37:406-412.

Hopkins, A.A. and C.M. Taliaferro. 1997. Genetic variation within switchgrass populations for acid soil tolerance. Crop Sci. 37:1719-1722.

Langdon, O.G., M.L. Bomhard, and J.T. Cassady. 1952. Field book of forage plants on longleaf pine-bluestem ranges. Occasional Paper 127, USDA, Forest Service, Southern Forest Experiment Station, New Orleans, La.

Martin, A.R., R.S. Moomaw, and K.P. Vogel.1982. Warm-season grass establishment with atrazine. Agron. J. 74:916-920.

McKenna, J. R. and D. D. Wolf. 1990. No-till switchgrass establishment as affected by limestone, phosphorus, and carbofuran. J. Prod. Agr. 3:475-479.
McMillan, C. 1959. The role of ecotypic variation in the distribution of the central grassland of North America. Ecol. Monogr. 29:285-308.

Moser, L.E. and K.P. Vogel. 1995. Switchgrass, big bluestem, and indiangrass, p. 409-420. In: R.F. Barnes, D.A. Miller, and C.J. Nelson (eds.) Forages Vol. I: An introduction to grassland agriculture (5th ed.). Iowa State Univ. Press, Ames, Ia.

Newell, L.C. 1968. Effects of strain source and management practice on forage yields of two warm-season prairie grasses. Crop Sci. $8: 205-210$

Sanderson, M.A., R.L. Reed, S.B. McLaughlin, S.D. Wullschleger, B.V. Conger, D.J. Parrish, D.D. Wolf, C. Taliaferro, A.A. Hopkins, W.R. Ocumpaugh, M.A. Hussey, J.C. Read, and C.R. Tischler. 1996. Switchgrass as a sustainable bioenergy crop. Bioresource Tech. 56:83-93.

Voigt, P.W. and R.S. MacLauchlan 1985. Native and other western grasses, p. 177-187. In: M.E. Heath, R.F. Barnes, and D.S. Metcalfe (eds.) Forages, the science of grassland agriculture ( $4^{\text {th }}$ ed.). Iowa State Univer. Press, Ames, Ia. 